\title{
REMONTAGENS DO TEMPO VIVIDO E NÃO VIVIDO: A TENTATIVA DE CAPTURAR O INOMINÁVEL
}

\section{ARTIGO ORIGINAL}

ROQUE, Isabel Rebelo ${ }^{1}$

ROQUE, Isabel Rebelo. Remontagens do tempo vivido e não vivido: A tentativa de capturar o inominável. Revista Científica Multidisciplinar Núcleo do Conhecimento. Ano 05, Ed. 12, Vol. 01, pp. 121-140. Dezembro de 2020. ISSN: 24480959,

acesso: https://www.nucleodoconhecimento.com.br/comunicacao/capturar-oinominavel

\section{RESUMO}

Este artigo tem por objetivo, a partir de certa perspectiva warburguiana, estabelecer alguns paralelos e um diálogo entre dois olhares estrangeiros sobre a Alemanha da Segunda Guerra Mundial e do pós-guerra - um, documental, do então jornalista, roteirista e soldado estadunidense Samuel Fuller; o outro, ficcional, do cineasta italiano Roberto Rossellini. Aproximações estéticas - a despeito de, em Fuller, tratarse mais de um "protocinema", mas que iria marcar a fogo sua obra como cineasta - e éticas, e eventuais desdobramentos, constituem vasto material que não se esgota neste texto. Além de tomarmos emprestado certo olhar do historiador da arte Aby Warburg, pelas pranchas de seu Mnemosyne enquanto espaço de interstícios e intersecções, sempre passível de composição e recomposição, buscaremos subsídios, para falar da obra de Fuller (Falkenau), em Georges Didi-Huberman. Ao tratarmos da obra de Rossellini que dialogará com a de Fuller, traremos algumas reflexões a respeito de seu filme que encerra a chamada "trilogia da guerra", Alemanha ano zero.

\footnotetext{
${ }^{1}$ Doutoranda em Comunicação e Semiótica.
} 
Palavras-Chave: cinema, cinema documental, ética, estética, história da arte.

\section{INTRODUÇÃO}

No início da versão do filme Alemanha ano zero (1948, Roberto Rossellini) distribuída nos Estados Unidos, inclui-se a seguinte narração in off:

Este filme não é um ato de acusação contra o povo alemão, nem tampouco uma defesa. É uma simples apresentação de fatos. Mas se alguém que tenha assistido à história de Edmund Koehler vier a concluir que algo deve ser feito, que as crianças alemãs devem ser ensinadas a amar novamente a vida, então, os esforços dos que fizeram este filme terão sido amplamente recompensados. (Alemanha ano zero, 1948.)

Em Alemanha ano zero, filmado por Rossellini depois de Roma, cidade aberta (1945) e Paisà (1946), estamos com certa segurança no terreno da ficção. A obra se insere no chamado neo-realismo italiano, e compõe com as duas outras produções a "trilogia da guerra" de Rossellini. Quando dizemos estar com certa segurança no terreno da ficção, o fazemos por ser conhecido de todos o fato de o cineasta reivindicar para seu cinema, à época, uma não representação, uma simples exposição dos fatos. Dir-seia que Rossellini ambicionava que seu cinema fosse menos ficcional e mais documental.

Tal ambição de Rossellini, contudo, não impediu que Alemanha ano zero fosse tratado com certo rigor por parte da crítica, que viu nele uma espécie de "traição" ao neorealismo na medida em que extrapolaria o que se reivindicava documental e inseriria uma simbologia e subjetividade em sua narrativa.

Não é, porém, exclusivamente sobre a obra de Rossellini que este trabalho pretende debruçar-se. Recuaremos uns poucos anos antes, até 1945.

\section{UMA CÂMERA NA MÃO E O HORROR DIANTE DOS OLHOS}

Até meados dos anos 1930 e início dos anos 1940, Samuel Fuller (1912-1997) trabalhava como jornalista em Nova York e havia escrito alguns roteiros para Hollywood, mas não pensava em se tornar cineasta: "Eu era repórter, era feito para 
perseguir a verdade. Nessa época, eu não estava interessado pela ficção (...)" (FULLER, 2002, p. 65, apud DIDI-HUBERMAN, 2018, p. 39).

Anos depois ele viria a se engajar na luta contra o nazismo, alistando-se em 1942 na Primeira Divisão da Infantaria do exército americano. Sua missão no Big Red One sua divisão da infantaria que lhe serviria de tema em uma produção de 1980 à qual voltaremos adiante - ia além da luta contra o nazismo: ele mais tarde escreveria que se tratava também de servir como eye-witness (testemunha ocular) "do maior crime da história deste século" (FULLER, 2002, p. 105, apud 2018, p. 39).

E tudo se deu quase que por casualidade. Fuller escrevera à mãe havia mais de um ano pedindo que lhe enviasse uma câmera, e esta só chegara pouco antes do momento sobre o qual nos detemos agora: uma pequena $16 \mathrm{~mm}$ Bell \& Howell com a qual ele viria a filmar suas primeiras imagens de cineasta.

Na noite de 7 para 8 de maio de 1945, o Big Red One chegou ao campo de Falkenau, na Tchecoslováquia. As primeiras imagens de horror a que Fuller teve acesso certamente ficariam impressas para sempre em suas retinas. Eis como, segundo DidiHuberman, ele as descreve (FULLER, 2002, p. 214, apud 2018, p. 39):

[...] Estava além de qualquer coisa crível, além de nossos pesadelos mais sombrios. Estávamos perturbados, nesse face a face com 0 massacre. Tremo ainda, ao me recordar dessas imagens de seres vivos desmoronados misturados com os mortos [...].

O que ele virá a filmar depois com sua 16 mm, sob as ordens de seu capitão, Kimbal Richmond, será um pequeno filme mudo com 20 minutos de duração, sem virtuosismo, sem cortes, sem montagem; seu "primeiro filme amador sobre matadores profissionais". Na descrição que dele faz Didi-Huberman (2018, p. 42-43):

Vemos homens que andam, munidos de pás. Vemos arames farpados, prisioneiros, soldados. Vemos homens em pé, silenciosos (diríamos, então, que o silêncio "técnico" do filme de Fuller se duplica por um silêncio bem mais fundamental). Vemos cadáveres nus, saídos de um prédio onde está escrito Leichenkammer [quarto fúnebre], depois vestidos com dificuldade pelos civis. Vemos uniformes do exército soviético. Vemos cadáveres vestidos postos em fila sobre lençóis 
brancos, no próprio chão, a cabeça mantida reta, as mãos cruzadas sobre o peito. Vemos, em um só plano, os arames farpados do campo e as casas da cidade próxima. Vemos grupos de homens agachados, depois de pé, em fileiras, diante dos cadáveres e numa encosta. Vemos um homem só que fala, provavelmente ele faz um discurso. Vemos saudações militares. Depois, uns quinze corpos carregados em duas carroças empurradas pelos civis através da cidade. Quando passam as carroças, a câmera filma as rodas e os pés dos que caminham, como se - olhar se abaixasse espontaneamente na passagem dos mortos. Vemos se estender o cortejo fúnebre.

E Didi-Huberman prossegue descrevendo a sequência seguinte, em que uma criança brinca com uma carabina de madeira enquanto um home tira o chapéu diante do cortejo.

[...] em seguida, numa grande fossa, no alto da colina, os cadáveres que são novamente deitados uns ao lado dos outros. Revemos os civis entre os quais um adolescente louro de calças curtas - colocar sobre todos os corpos um grande sudário feito de lençóis ou de pedaços de tecido reunidos.

Esse pequeno conjunto de imagens, sem edição, sem narração, ao qual Fuller deu o simples título de Falkenau (o nome do campo de prisioneiros), ficaria engavetado por mais de quarenta anos, mas viria a marcar profundamente toda a sua produção cinematográfica e estaria subjacente a suas maiores entrevistas - em especial às que concedeu aos Cahiers du Cinéma. Em suas palavras: "Jornalismo, guerra, cinema... essas três palavras designam o que faz, hoje, girar o mundo mais vertiginosamente que nunca", e, ainda, se a guerra mata e o jornalismo conta, "o cinema faz reviver essas emoções" (NARDONI e SIMSOLO, 1986, p. 13, apud 2018, p. 50).

Em sua filmografia, podemos afirmar sem risco de erro que a guerra ocupa lugar central, seja como tema, seja como ideia: guerra contra o racismo, guerra contra a intolerância. $O$ que distingue seus filmes do que seria de esperar de filmes em que subjaz a "guerra" é que neles não há o culto à figura do herói, mas sim à do sobrevivente: "Não há heróis em meus filmes. São sobreviventes da guerra, eles apenas fizeram o que era preciso para ficarem vivos (SERVER, 1994, p. 52, apud 2018, p. 50-51). A essa altura, Didi-Huberman nos chama a atenção para um ponto 
que nos será especialmente relevante mais à frente, ao dispormos, em nossa prancha warburgueana, Fuller lado a lado com Rossellini (2018, p. 51):

Contra a "cobertura açucarada" (sugar coating) que denunciava no cinema hollywoodiano, Fuller reivindicou - notadamente num diálogo célebre com Howard Hawks - um cinema "artístico" tanto quanto "verídico": "Make it artistic. But show the truth" (Faça isso artisticamente. Mas mostre a verdade).

E, em seguida:

Utilizei meu conhecimento direto (firsthand knowledge) para criar filmes que, espero, mostravam a verdade a propósito dos homens em tempo de guerra. (...) Odeio a violência. Isso não me impediu de utilizá-la em meus filmes. Ela faz parte da natureza humana [...]. A guerra não tem a ver com emoções. Tem a ver com ausência de emoções. Essa ausência, esse vazio (that void) é isso, é a emoção da guerra. [...] Pois bem, as palavras sozinhas não podem descrever isso. (FULLER, 2002, p. 219, 234 e 291, apud 2018, p. 51)

O episódio vivido por Fuller em Falkenau, além dos anteriores, enquanto esteve na Primeira Divisão da Infantaria - no Norte da África, na Sicília, na Normandia, onde foi condecorado por bravura, na Bélgica, na Alemanha e, por fim, na Tchecoslováquia deram origem a um romance, escrito por ele provavelmente em torno de 1959 e a um filme, que só viria a ser produzido em 1980. O livro foi publicado também em 1980. Ambos receberam o título The Big Red One (no Brasil o filme receberia o título de Agonia e glória). A montagem final do filme foi bastante truncada, contra a vontade de Fuller, e nos créditos iniciais o cineasta declara: "Este filme é constituído de vidas imaginárias (fictional life) baseadas sobre os mortos reais (factual death)" (FULLER, 2002, p. 122, 219, 382-383 e 475-483, apud 2018, p. 51).

Fuller já havia tentado filmar The Big Red One em 1959, possivelmente pela inquietação de levar à luz o que testemunhara em Falkenau e dar ao episódio um sentido narrativo ao público, fazê-lo cumprir sua missão primeira e pedagógica: a de servir como lição à humanidade - voltaremos a isso mais adiante. Seus planos, porém, foram frustrados. Ainda assim a ocasião serviu-lhe como delimitador de espaço ou de, se assim podemos chamar, "universo imagético". Explicamos: o ícone hollywoodiano John Wayne oferecera-se para interpretar a personagem do sargento à frente da 
Primeira Divisão da Infantaria. Fuller, porém, o descartara de imediato. O que ele menos queria era que a personagem fosse vista como "herói", e que seus atos fossem interpretados como "patrióticos" (FULLER, 2002, p. 383, apud 2018, p. 52). Daí sua escolha, quando finalmente daria seguimento à produção do filme, em 1980, por Lee Marvin (2018, p. 52):

Ele queria, antes, construir seu filme a partir de algo como um "lirismo seco" (dry lyricism) [2002, p. 482] para mostrar, em suma, essa "emoção da guerra" feita do "vazio" ( void) de toda emoção nas situações de perigo extremo onde é o corpo em movimento que decide tudo, quase automaticamente, para além da expressão normal das emoções. A escolha de Lee Marvin para interpretar o sargento devia contribuir com isso, seu rosto macilento, pouco expressivo, sendo para Fuller o próprio rosto, impessoal, da morte: "O rosto da guerra mais enrugado, fatigado, mais cadavérico possível, mas precisamente por causa disso a morte não pode atingi-lo". (2002, p. 320, apud 2018, p. 52)

Didi-Huberman chama-nos a atenção, entretanto, para o fato de que nem por isso o filme de Fuller deixa de ser inteiramente construído - dentro da estética hollywoodiana que o faz pertencer à estirpe do cinema de ação. E, mesmo aí, a grandiosidade do filme e de seu diretor e roteirista está em não trair nem sua vivência nem sua obra: no episódio final, em que recria à sua maneira o vivido em Falkenau, Fuller escolhe a "economia dos meios" e faz tirar de cena o "pathos da ação":

Tudo isso para suscitar, numa cena em que a ação não tem mais sentido, o pathos da indignação diante de uma realidade que o filme de guerra, enquanto gênero, fracassa certamente em representar. (2018, p. 52)

Poder-se-ia a esta altura pensar que em 1980 estaria finalmente revelada para o mundo a narrativa por trás dos cerca de vinte minutos registrados pela $16 \mathrm{~mm}$ que Fuller empunhara em 1945, em Falkenau. Nada mais distante da verdade. Não nos esqueçamos do que Fuller dissera a Hawks: "Make it artistic". The Big Red One era antes de tudo um filme de guerra, de Samuel Fuller, mas também de Hollywood.

Foi somente em 1986 que, ao conceder entrevista ao cineasta francês Emil Weiss (1947-), este o convenceu a pensar sobre um modo de tornar visíveis as imagens capturadas em 1945 em Falkenau. Histórica e politicamente, o momento não poderia ser mais propício: Shoah (Holocausto), documentário de 1985 do cineasta francês 
Claude Lanzmann (1925-2018), era ainda recente na memória do público. Ao mesmo tempo, o negacionismo acerca do horror do nazismo tomava corpo de modo quase incontrolável, a ponto de exigir uma verdadeira conjuração de forças daqueles que julgassem relevante preservar os testemunhos da historiografia para as gerações futuras.

É nesse estado de coisas, conforme sinaliza Didi-Huberman, que Weiss e Fuller assumem para si como missão dar uma resposta direta ao tristemente célebre "detalhe" a que Jean-Marie Le Pen se referiu em 1987. Na ocasião, Le Pen, líder do partido francês Frente Nacional, de extrema direita, sugeriu que as câmaras de gás teriam sido apenas um "detalhe" da Segunda Guerra Mundial, informação que, aliás, consta oficialmente da Cronologia da Negação do Holocausto, na página oficial do United States Holocaust Memorial Museum².

A absurda afirmação de Le Pen seria repetida anos depois, em 2015:

A Corte de Cassação, a mais alta jurisdição francesa, confirmou nesta terçafeira [27/03/2018] a condenação de Jean-Marie Le Pen, fundador do partido de extrema-direita Frente Nacional (FN), a uma multa de $€ 30$ mil - o equivalente a cerca de $R \$ 120$ mil. A punição é por ele se referir novamente às câmaras de gás nazistas como um "detalhe" da Segunda Guerra Mundial.

\section{$(\ldots)$}

Em 2 de abril de 2015, o apresentador de TV Jean-Jacques Bourdin perguntou a Le Pen se ele lamentava ter chamado as câmaras de gás de "detalhes". O político respondeu: "De maneira alguma. O que eu disse corresponde ao meu pensamento de que as câmaras de gás foram um detalhe da história da guerra, a menos que admitamos que a guerra é que é um detalhe das câmaras de gás"(...) ${ }^{3}$.

\subsection{PARA DAR LEGIBILIDADE AOS FATOS}

Os fatos de legibilidade (nas palavras de Didi-Huberman) aos quais a montagem de 1988 sobre o filme de 1945 nos dá acesso nos levam a algumas questões. A primeira delas é a do autor, uma vez que nos créditos escritos de modo improvisado não aparece o nome de Samuel Fuller, e sim: "Supervisionado pelo capitão Kimbal [sic] R. 
Richmond, apresentado pelo $16^{\circ}$ segmento de infantaria comandado por Frederick W. Gibb, $1^{\text {a }}$ divisão de infantaria; Falkenau, 9 de maio, 1945”. Em 1988, Fuller viria a comentar: "Richmond é o verdadeiro autor do filme", uma vez que a decisão de organizar todo aquece ritual foi dele. Depois, Fuller diria: "pode-se dizer que a história foi escrita por ela própria". Não há "autor", uma vez que as pessoas que vemos não são personagens nem "criaturas" daquele que as filma. Poder-se-ia, assim, quase dizer que os seres filmados em Falkenau deixaram Fuller mudo durante quarenta anos (2018, p. 55-56).

O segundo fato de legibilidade é a questão da prova visual, ou, no inglês, evidence. Em sua filmagem de 1945, isso se evidencia em dado momento em que Fuller, na produção de 1988, explica o fotograma que descrevemos antes nas palavras de DidiHuberman ("Vemos, em um só plano, os arames farpados do campo e as casas da cidade próxima"):

Aqui estão as casas; o campo estava atrás. É um plano sem corte, sem montagem. Apenas fiz uma panorâmica a partir das casas até o campo. Vejam como estão perto! Não fiz nenhum corte. Não era para fazer. Brincando sobre essa colina, as crianças certamente deviam ver no interior do campo. (Samuel Fuller, Falkenau, 1945. Filme $16 \mathrm{~mm}$, preto e branco. Fotograma. apud 2018, p. 43.)

Em The Big Red One, Fuller dá a essa mesma situação outra solução de composição de cenas; entretanto, em sua filmagem "bruta" de 1945, há uma intencionalidade que não é artística, mas sim de produção de evidências. Daí, também, na análise de DidiHuberman, para muitos dos primeiros planos, acompanhados da ordem de que as pessoas filmadas olhassem na direção da câmera, a fim de que seu rosto fosse posteriormente identificável. Estávamos, portanto, no terreno do fotojornalismo.

O terceiro fato de legibilidade é o que extrapola a prova, a evidência, é aquilo a que nenhuma imagem dá conta de nos permitir acesso: para além da prova está a provação. Trata-se do ar das imagens, a Atmosphäre: o odor que emana não só dos cadáveres como também dos corpos dos doentes e que invade todo o espaço. Um odor de carnes gangrenadas e que, para os soldados americanos, torna ainda mais 
insuportável a denegação dos camponeses de que tivessem conhecimento do horror que se passava diante de seus olhos e narizes.

O quarto fato de legibilidade é, aponta Didi-Huberman, como para extrair acima de tudo um ponto de vista ético sobre todo esse estado de coisas, uma tentativa de Fuller e sua câmera de se aproximar dos rostos. Em seus enquadramentos, ele busca os olhares, se detém nos gestos - exceto quando baixa os olhos diante da passagem das carroças fúnebres.

Chegamos ao quinto fato de legibilidade: a dignidade. Trata-se aqui da "breve lição de humanidade em 21 minutos" a que se refere Fuller no filme de 1988: cada um dos camponeses e notáveis de Falkenau teve, sob as ordens de Richmond, de pegar respeitosamente os mortos, vesti-los pacientemente, transportá-los em carroças funerárias, um dos que observavam o cortejo à beira do caminho recebeu a ordem de tirar o chapéu, todos tiveram de, respeitosamente descer um a um dos mortos à grande sepultura cavada em uma colina do cemitério, vários tiveram de cobri-los respeitosamente com lençóis como se fossem mortalhas, um jovem de calças curtas foi ameaçado por Richmond de ser baleado na cabeça se, durante sua tarefa de cobrir os mortos, ousasse pisar em um deles, por último todos tiveram de enterrá-los e marcar o lugar de seu repouso digno. Eis o ritual. Eis a restituição, a vivos e mortos, a vencedores e vencidos, de sua humanidade.

\subsection{LIÇÕES DE HUMANIDADE: A INOCÊNCIA DO OLHAR}

Didi-Huberman, que é quem em grande medida norteia o olhar que aqui lançamos sobre a obra de Fuller, dedica a seu sexto fato de legibilidade um item à parte. É exatamente esse 0 item que, a par de alguns aspectos relativos à estética cinematográfica, nos interessa relacionar ao cinema de Rossellini, notadamente em seu Alemanha ano zero: o do trabalho de pedagogia do qual as imagens seriam capazes apesar de tudo.

A quem essa "lição" se destina? [...] Poder-se-ia dizer, doravante, que se destina às crianças, isto é, ao futuro da memória. O cinema de Fuller é, em geral, obcecado pela infância. Em The Big Red One, em particular, 
os garotos tornam-se, por assim dizer, os atores principais da História com um $\mathrm{H}$ maiúsculo - enquanto são personagens secundários na narrativa -, aqueles que querem ou não aprender a lição, como o jovem siciliano que carrega com ele o cadáver de sua mãe, a menina que trança flores sobre o capacete do soldado, o rapazinho hitleriano que recebe palmadas em vez de ser fuzilado, ou a criança do campo que morre, olhos esbugalhados, sobre o ombro do sargento. No filme de 1945, não se vê somente uma criança que brinca na beira da estrada com seu fuzil de madeira, vê-se também um jovem de calças curtas que, na fossa comum, recobre os mortos com um tecido branco; Fuller conta que Richmond o havia ameaçado de morte se ele ousasse somente colocar o pé sobre um dos cadáveres ("Se você pisar num corpo, eu te mato"). Mais tarde, na filmagem de 1988, Fuller explicará como às crianças o sentido da expressão Arbeit macht frei [o trabalho liberta, inscrição que se via à entrada de Auschwitz]. (DIDI-HUBERMAN, 2018, p. 61)

Fuller deseja, portanto, legar às gerações futuras uma lição, uma mensagem. Mas ele sabe que o Samuel Fuller que empunha aquela $16 \mathrm{~mm}$ em $1945 \mathrm{sob}$ as ordens do capitão Richmond é de certo modo também uma criança, que ainda não sabe o que fará mais tarde das cenas que seu olhar captura.

Quando um campo se abre, olha-se, estupefato, pega-se tudo o que é possível, sem fazer por mal. Depois, trata-se de escolher, compreender, de pensar o mal. Quando um campo se abre, a questão é filmar tanto quanto possível e "executar simplesmente os gestos do cinema", o que supunham para Fuller, andar no espaço de horror, câmera na mão, esta pequena câmera manual que gravava as imagens em velocidades irregulares e que dá ao filme de 1945 um ritmo tão "primitivo". Trata-se, mais tarde, com Emil Weiss, de sentar-se à mesa de montagem para dar a essa filmagem original seu valor de legibilidade histórica. (DIDIHUBERMAN, 2018, p. 63-64)

De certo modo, como escreveu o crítico francês Serge Daney (1944-1992),

Era preciso ser americano - isto é crer na inocência fundamental do espetáculo - para fazer desfilar a população alemã diante dos túmulos abertos, para Ihe mostrar ao lado do quê ela tinha vivido, tão bem ou tão mal. (1994, p. 24, apud 2018, p. 63)

\section{LIÇÕES DE ÉTICA: DE FULLER A ROSSELLINI}

Anos depois de legar ao mundo algumas das obras-primas do neorrealismo italiano, como Roma, cidade aberta, Paisà e Alemanha ano zero, Roberto Rossellini (1906- 
1977) decide deixar o cinema pela televisão. Na nova mídia, à época ainda uma promessa, dedica-se a produções cujo tema é a vida de alguns dos maiores filósofos do pensamento ocidental, como Sócrates e Descartes. Rossellini vê nessa mídia uma possibilidade até então inimaginável para o cinema: levar informação a todos. Com o tempo, entretanto, também a televisão o desencantará. Em Fragmentos de uma autobiografia (1992a, p. 19), escrito poucos meses antes de sua morte, em 1977, ele afirma:

Os meios de comunicação que, em princípio, deveriam dissipar a escuridão, nada mais fazem do que difundir a ignorância à força de simplificações redutoras e de esquemas preparados de antemão. Abrangem uma parte mínima do saber, contentando-se em fornecer à dialética mental aquilo que necessita para seu consumo cotidiano, ignorando tudo o mais.

As mídias são grandemente responsáveis pela situação de angústia e de confusão em que nos encontramos. [...]

Na mesma obra (1992a, p. 10-11), Rossellini alerta:

Já é tempo de esclarecer um equívoco fundamental a meu respeito e vou fazê-lo: eu não sou um cineasta.

Mesmo tendo nesse setor uma espécie de habilidade, o cinema não é meu ofício. O meu ofício é necessário aprender cotidianamente, e sua descrição não será exaustiva: o ofício de ser um homem.

Talvez derive daí a grandiosidade da obra que Roberto Rossellini nos legou: mais que exercer o ofício de cineasta, a ele interessou, até o fim, aprender a ser um homem, ou, tomando emprestada a expressão de Nietzsche, tornar-se quem ele de fato era.

Alemanha ano zero é um dos primeiros filmes - senão o primeiro - a ter como protagonista uma criança em meio a um cenário de guerra ou pós-guerra. Outros viriam depois, como Os incompreendidos, de François Truffaut, $A$ infância de Ivan, de Andrei Tarkovski, Império do Sol, de Steven Spielberg etc. Poder-se-ia, porém, dar a Alemanha ano zero, ou, melhor, a seu protagonista, um clamor ou grito que sobrepuja a todos os outros. 
Para além da personagem está-se diante de um corpo todo ele uma enunciação: aquele corpo é, em si mesmo, um discurso. Falar de Edmund Koehler é, portanto, falar de todos os outros meninos, ou de uma "protoforma" de todos eles.

Alemanha ano zero se segue a Paisá, filme em seis episódios que tratam de encontros entre italianos recém-libertados e soldados que os americanos que os libertaram. Roma, cidade aberta, o filme anterior, tratava da ocupação pelos nazistas e da resistência da população a eles. Tanto um como o outro foram recebidos com entusiasmo por críticos e público. Ambos, também, são considerados "legítimos" representantes do neo-realismo italiano.

E o que dizer de Alemanha ano zero? Conforme expusemos anteriormente, certa parcela da crítica o considerou demasiadamente simbólico, desviando-se do neorealismo. Quanto à sua decisão por realizá-lo, em seu livro My Method (1992b, p. 21), Rossellini refere-se a dois grandes temas relativos à experiência da guerra: o primeiro, as bombas atômicas sobre o Japão, o segundo a destruição da Alemanha. Como europeu, ele se sentia mais capacitado a falar sobre o segundo.

Depois de obter das autoridades da ocupação francesa na Alemanha a autorização para filmar em Berlim, ao chegar lá Rossellini saiu dirigindo, sozinho, ainda sem um roteiro definido. Eis suas primeiras impressões:

A cidade estava deserta, o cinza do céu parecia correr nas ruas e, da altura de um homem, se podiam ver todos os telhados; a fim de localizar as ruas sob as ruínas, eles haviam afastado e empilhado os escombros; nas rachaduras do asfalto, o mato começara a crescer. O silêncio imperava, e cada ruído, em contraponto a isso, o sublinhava ainda mais; o odor agridoce de material orgânico em decomposição constituía uma parede sólida através da qual se devia passar; você flutuava sobre Berlim. (ROSSELLINI, 1955, apud BRUNETTE, 1996, p. 77; tradução nossa do inglês.)

Sabemos, das leituras sobre como se deu a pré-produção de Alemanha ano zero, que Rossellini recrutou seus atores enquanto dirigia pelas ruas entre ruínas de Berlim. Enquanto isso, um de seus roteiristas, Carlo Lizzani, tratava de coletar informações sobre a juventude alemã. 
Finalmente, acabamos com cerca de quinze páginas na mão, as quais, entretanto, eram quinze páginas muito precisas. Cada folha continha uma sequência e cada sequência era extremamente clara. Por exemplo: "Um cavalo cai, pessoas se aglomeram em torno do cavalo morto, o esquartejam, cada um pega um pedaço de carne, a criança vê a cena, passa por perto e vai embora." Então, essa grande cena foi na verdade escrita em três linhas, mas eram três linhas muito precisas. Rossellini tinha essa capacidade de concentrar e sintetizar sua história em umas poucas linhas e em cenas muito claras. (FALDINI \& FOFI, 1976, p. 111, apud BRUNETTE, p. 77; tradução nossa do inglês.)

Em suas palavras, ele também escolhera como protagonista uma criança como forma de acentuar o contraste entre a mentalidade de uma geração nascida e crescida em meio a uma certa atmosfera política e uma geração mais velha, representada pelo pai do protagonista. "Se ele [Edmund] provoca pena ou horror, eu não sei, nem desejei saber. Eu queria reproduzir a verdade, sob o impulso de uma forte emoção artística" (1992b, p. 21, tradução nossa do inglês).

garoto Edmund Meschke, que interpreta o protagonista Edmund Koehler de Alemanha ano zero, assim como todos os demais atores do filme, foram recrutados por Rossellini nas ruas de Berlim. Edmund Meschke, ao chegar para as filmagens, assombra a equipe de Rosselini, tamanha a semelhança física com Romano, o filho do diretor nascido em 1937 e que morrera pouco antes. É a Romano que Rossellini dedica o filme.

Edmund Koehler, o protagonista, tem, em 1947, cerca de 12 anos de idade. Terá nascido, portanto, pouco antes de eclodir a Segunda Guerra Mundial. Sua primeira infância se deu em uma Alemanha que vivia sob o delírio do nazismo de Adolf Hitler. Poder-se-ia inferir que em 1947 se esteja diante de um Edmund adolescente, amadurecido à custa do sofrimento e da penúria. No entanto, logo em sua primeira aparição na tela, o que vemos é um garoto franzino, vestindo calças curtas e um paletó de homenzinho, e o que ouvimos é uma voz demasiado infantil para sua idade.

Ao longo de pouco menos de noventa minutos, acompanhamos a perambulação de Edmund entre escombros, em busca de pequenos trabalhos que lhe garantam levar algum dinheiro ou suprimentos para a família, que divide o mesmo espaço com outras 
famílias. A irmã, Eva, sai à noite com outras jovens e consegue cigarros (os quais irá vender depois) com soldados aliados que ocuparam Berlim. Ao contrário das demais, Eva recusa-se a se prostituir, pois espera que o namorado retorne do campo de prisioneiros. Karl-Heinz, o irmão, ex-oficial da SS, mantém-se escondido na casa, temendo que, caso se apresente às autoridades, seja conduzido a algum campo de prisioneiros. O pai encontra-se entrevado em uma cama. Como somente Edmund, a irmã e o pai recebem cupons de alimentação, o garoto tem de se desdobrar ainda mais para sustentar a todos.

Com uma história que teria tudo para resultar em um “dramalhão”, Rossellini mantém uma narrativa fria, quase documental. Um cinema que, como o diretor afirmou mais de uma vez: "não demonstra, mostra".

\section{O ANO ZERO DA ALEMANHA}

Pedimos licença, aqui, para acrescentar uma nova peça à nossa prancha warburguiana: recuamos agora a 1946, quando, aos 25 anos de idade, Edgar Morin publica seu primeiro livro: $O$ ano zero da Alemanha. Em seu prefácio à edição brasileira (2009), ele explica que o título na verdade havia sido concebido por seu amigo Robert Antelme, que pretendia usá-lo na narrativa de sua experiência em um campo de concentração. Antelme, porém, desistiu do título e o cedeu a Morin.

Embora Rossellini jamais o tenha declarado em seus escritos e entrevistas, algumas informações dão conta de que ele teria, posteriormente, pedido e obtido de Morin licença para usar a expressão "ano zero" no título de seu filme - o que nos leva a especular que o livro tenha sido uma possível fonte para o desenho que Rossellini faz da Alemanha e, principalmente, da juventude alemã.

Deliberadamente ou não, Alemanha ano zero conclui a Trilogia da Guerra de Roberto Rossellini apresentando uma espécie de enigma filosófico, fato já sinalizado por seu título, que ele emprestou, com permissão, de um livro do sociólogo francês Edgar Morin. Foi um título que confundiu até mesmo Joseph Burstyn e Arthur Mayer, os produtores americanos de Roma cidade aberta e Paisà; e o fato de Rossellini, como de hábito confiando em seus instintos, ter-se recusado a explicitar 
seu significado, acabou por levá-los a desistir do projeto, que viria a ser em grande parte financiado pelo governo francês ${ }^{4}$.

A ida de Morin para a Alemanha decorrera de sua apresentação como voluntário para auxiliar na gestão dos territórios alemães ocupados pelos aliados. Essa primeira obra, como o próprio Morin admite, ressente-se ainda de certa inexperiência; isso, porém, não invalida algumas análises bastante argutas do que ele viu e ouviu ao viajar pelo país recém-derrotado.

Em O ano zero da Alemanha (2009), Morin empreende um esforço por entender o que sentem os alemães: não à toa, a primeira parte do livro se intitula "Como é possível ser alemão?". Curiosamente, logo às primeiras páginas do livro, como se precisasse que mais alguém desse testemunho do retrato que iria traçar, ele recorre ao relato sobre uma entrevista feita não por ele, mas pelo escritor e jornalista soviético Vasily Grossman (1905-1964).

Morin nos conta que, em sua viagem à Alemanha, Grossman teve uma conversa com um jovem estudante, oficial da Whermacht. Ao lhe indagar sobre os assuntos com que ele gostava de se entreter à noite, o jovem refletiu por um momento e respondeu: "Os sentimentos. Tentamos descobrir o que isso significa". Pensando que o jovem não houvesse compreendido a pergunta, Grossman a repetiu. O jovem, então, Ihe explicou que os jovens de sua geração não sentiam absolutamente nada e discutiam horas a fio para descobrir como poderiam chegar a experimentar sentimentos como amor, piedade, ódio, indignação. "Isso, porém, não leva a nada. Nós não podemos mais sentir" (2009, p. 32-33). E Morin conclui: "Das ideias e sentimentos só restaram cinzas. Os alemães exibem uma ruína tão absoluta quanto a ruína de suas cidades" (2009, p. 33).

Mais adiante, o livro apresenta um capítulo inteiro aos jovens alemães: "A juventude alemã pode ser salva?" (2009, p. 83). Há outros momentos na obra, mas esse capítulo, em especial, nos parece ecoar algumas aproximações com a obra de Rossellini melhor seria, talvez, dizermos o contrário. Em que medida, arriscamos, o cineasta italiano não teria trazido dessa leitura algo além do nome? 
Ao mesmo tempo que Morin nos fala de um país devastado e de uma juventude entregue à própria sorte, também é corajoso ao fazer uma espécie de "mea culpa em nome dos Aliados" que ocupavam o território alemão à época de sua narrativa: ingleses, franceses, norte-americanos e russos. A segunda parte de seu livro é fortemente crítica ao denunciar o fato de que os Aliados aniquilaram a Alemanha (obviamente como "efeito colateral" de seu objetivo maior: derrotar Hitler e o nazismo), ocuparam seus territórios e... não construíram nada no lugar.

Morin, em seus 25 anos de idade, se mostra alarmado diante do risco que essa omissão ou inoperância representa em um país que ainda vive imerso em um universo de mitos, tanto ideológicos como políticos. Um caldo de cultura altamente propício para fazer vicejar certa nostalgia, certo sentimento de orfandade diante da perda do pai, o Führer. Poder-se-ia dizer, ao ler tal relato: Hitler está morto, mas a serpente segue ali, pondo seus ovos. Ao ler $O$ ano zero da Alemanha, podemos tomar conhecimento, estupefatos, de quanto os próprios Aliados colaboraram para a sobrevivência da ideologia nazista.

\section{O OVO DA SERPENTE}

Entre "bicos" que arruma para conseguir algum dinheiro, Edmund perambula pelas ruas de Berlim. Logo em uma das primeiras cenas o vemos parar diante de uma aglomeração de pessoas, curioso. Um cavalo acabara de cair, sem vida, talvez de fome ou exaustão. Um dos observadores se antecipa com uma faca e começa a the retalhar a carne. Os demais observam ávidos, à espera de sua vez. Mais assemelhada a um bando de abutres, é difícil enxergar naquela gente o povo que, até pouco mais de dois anos antes, seguia acreditando em sua superioridade diante do mundo. [Lembremos: trata-se da cena que Lizzani nos revela não ter ocupado mais de três linhas no roteiro de Rossellini.]

Um guarda expulsa da cena Edmund, que então volta à sua perambulação. A fotografia em preto e branco parece acentuar a sensação de estarmos, com ele, em um cenário desolado, de pedaços de concreto, pedras e pó. Há, entretanto, o que se tenha preservado: uma fonte no centro de uma praça, o prédio da Chancelaria. É 
nessa praça que Edmund encontra Henning, seu antigo professor. Logo vemos tratarse de alguém que mantém vivos os ideais nazistas. É ele quem traz novamente a Edmund os ecos do nazismo.

Henning divide com outros nazistas um casarão na periferia de Berlim, além de aliciar um grupo de jovens pouco mais velho que Edmund para que pratiquem pequenos furtos e apliquem golpes. É assim que ele dá a Edmund sua primeira missão: levar até as escadas da Chancelaria um disco e um fonógrafo, e pô-lo a tocar para que algum dos soldados britânicos o queira comprar. Na verdade, as intenções de Henning não ficam claras: seu objetivo pode ser, para além do de obter algum dinheiro, o de fazer uma provocação aos invasores, ou, talvez, fazer reerguer-se o mito, acordar em seus concidadãos o espírito de lealdade ao Führer.

A voz do Führer ecoa pelas ruínas e pelas paredes da Chancelaria. Em um lapso de suspensão do tempo, o ar se torna pesado e irrespirável. É então que vemos um homem já de certa idade e uma criança de 2 ou 3 anos caminharem, lentos, por um longo corredor externo. Por um instante eles param e olham na direção de onde vem o som. Em seguida, retomam o passo. Certamente a criança não sabe do que se trata. O homem, entretanto, lembra-se bem da voz que ouve. É por isso que, passada a surpresa, retoma o passo, levando pela mão a criança, como se estivessem ali, como nos diz Brunette (1996, p. 81), a representar a velha e a nova Alemanha.

Há outro momento em que o som impera em cena. É bem mais adiante, quando Edmund já cometeu o parricídio por influência de Henning e perambula sem rumo como em fuga diante do que fez. De uma igreja, emerge o som de um órgão e brevemente vemos lá dentro quem o toca: um sacerdote. A descrição de Brunette para essa cena, que transcrevemos a seguir, enfatiza o entrelaçamento que Rossellini faz, em uma só e breve cena, de três expressões artísticas - o cinema, a música e a pintura:

A certa altura, ele passa diante de uma igreja em ruínas devido a um bombardeio, e o som de um órgão preenche o vazio; pessoas param na rua em pequenos e estilizados grupos, como em uma reminiscência de paisagem urbana pintada por De Chirico. Após uma pausa de um 
momento ou dois, Edmund se afasta do inútil consolo da igreja institucional - inútil, afinal, a essa altura da sua vida e da vida de uma Europa exaurida (BRUNETTE, 1996, p. 85; tradução nossa).

\subsection{O DISCURSO MUDO - E ELOQUENTE - DE EDMUND}

O que nos comunica o corpo-fiapo, o corpo-sombra de Edmund? Esse corpo não age; apenas reage, ou melhor, é agido. Daí em certos momentos termos a impressão de um olhar inexpressivo, como o de um autômato. Edmund está em um não-lugar, uma não-infância. Daí, também, sua vulnerabilidade a tudo o que vê e ouve. O corpo de Edmund é uma esponja que a tudo absorve e não devolve. Um corpo que, saturado e à deriva, sem lugar entre os adultos, entre as crianças menores e entre as crianças maiores, entrega-se por fim ao jogo, à infância sem lugar.

Dissemos antes que, ao longo de pouco menos de noventa minutos, acompanhamos Edmund em sua perambulação, seu eterno caminhar sem parecer ter para onde. Se Alemanha ano zero impressiona pela horizontalidade das sequências, há que destacar também nele momentos de relativa ou radical verticalidade - como no subir e descer de escadas, ou na exploração que Edmund faz do edifício inacabado e já em ruínas onde virá a saltar para a morte. Esse constante deslocamento contrasta com os efeitos que Rossellini extrai dos interiores - o de intensa claustrofobia. Os closeups que se alternam de modo quase vertiginoso nos diálogos entre as personagens parecem potencializar a percepção de conflito ou de tensão crescente.

Em diversos momentos, também, seja nas cenas externas seja nas internas, o cineasta extrai dos enquadramentos e da movimentação das câmeras em torno de Edmund um quase sufocamento deste pelo mundo dos adultos - assim é quase ao início, na sequência em que Edmund tenta ganhar uns trocados cavando covas em um cemitério, ou nas sequências em que ele interage com as pessoas do andar onde vive. É também no jogo de luz e sombra que percebemos adensar-se o conflito do corpo de Edmund entre o fora e o dentro de si. Esse jogo atinge talvez seu ápice na sequência quase fantasmagórica em que o menino prepara o chá com que envenenará o pai, cuja voz, ao fundo, parece ironicamente encorajá-lo ao ato - tanto quanto parece tê-lo feito o professor nazista. 
Nos minutos que nos encaminham para o desfecho do filme, seguimos pelos pés de Edmund, pulando poças, escalando amontoados de pedras, inventando uma arma de uma cabeça de martelo - chegamos a evocar o garoto que Fuller capturou com sua $16 \mathrm{~mm}$ brincando com uma arma de madeira em Falkenau. A "arma" de Edmund será a mesma que ele apontará para a cabeça, depois para a própria sombra e, por fim, para o prédio em ruínas onde até pouco tempo vivia - para depois arremessá-la contra ele. Ao longo dessa sequência, descobrimos enfim o Edmund criança: pela primeira vez seu corpo de fato age. Edmund reencontra sua infância e brinca. Daí sermos surpreendidos pelo que vem a seguir: após levar a mão aos olhos, quem sabe saturado de tanto ver, Edmund se lança para a morte. O que se segue à queda do corpo, mais uma vez, remete a outra forma de arte: a escultura. A vizinha que vê o pequeno corpo sem vida se deixa cair, sem forças, diante dele, as mãos inertes de cada lado do colo. Como nos diz Brunette, "onde se esperaria uma Pietà (...) não há contato entre os corpos" (1996, p. 86; tradução nossa).

Morin, no capítulo que dedica à juventude alemã de seu Ano zero da Alemanha, nos fala do "isolamento" a que o regime nazista teria condenado sua juventude (aqui entendida a juventude que, ao fim da guerra, ainda não teria 18 anos de idade): primeiro um isolamento vaidoso, depois, um isolamento desumano, por fim, o isolamento do desespero (2009, p. 101). Que mais poderíamos dizer acerca do que o corpo-sombra de Edmund encerra?

Todo esse panorama nos mostra a encruzilhada em que à época a Alemanha se encontrava. Entre o velho e o novo, como escreve Morin, "nada é mais desmoralizante do que ver o mato crescer em meio às ruínas" (2009, p. 67). Poderíamos aqui arriscarnos a aprofundar uma reflexão, ou "estado da arte" daquele país, naquele momento de impasse, bem como nos anos que se seguiriam, os da reconstrução. Não é, porém, o que nos interessa. Entre a criança de 2 ou 3 anos levada pela mão do velho, que nada sabe do que se passou, e o velho, que tudo viu, interessa-nos, mais uma vez, Edmund.

O sentido que Rossellini quis dar a seu relato, ao tomar emprestado de Morin o nome que este recebera de Antelme, "ano zero", parece-nos suficientemente claro a ponto 
de dispensar qualquer análise. Talvez não tenha sido gratuita, também, sua escolha para o nome de seu protagonista: Edmund, do germânico Hedmund, união dos elementos ead, "riqueza, bens", e mundo, "proteção".

Edmund, protetor da riqueza. O que não viu retorno ao antes nem vislumbrou qualquer caminho à frente. $O$ ano zero da Alemanha. $O$ que se imolou, lançando-se de encontro a ruínas, sob um céu em que não mais se viu protegido e em que tampouco pôde mais encontrar seu oxigênio.

Os alemães eram seres humanos como os outros; o que poderia tê-los levado a tal desastre? A falsa moralidade, a essência mesma do nazismo, o abandono da humildade pelo culto do heroísmo, a exaltação da força no lugar da falibilidade, o orgulho contra a simplicidade. Eis por que escolhi contar a história de uma criança, de um ser inocente que a distorção de uma educação utópica leva a perpetrar um crime na crença de realizar um ato heroico. Mas a pequena chama moral não se extingue nele: ele se suicida para escapar a esse desconforto, a essa contradição. (ROSSELLINI, 2006; tradução nossa)

\section{CONSIDERAÇÕES FINAIS: UM ENCONTRO ESTÉTICO E ÉTICO}

Um dos aspectos que mais chama a atenção quando se assiste a Alemanha ano zero é a inexpressividade dos atores, em especial de seu protagonista. Como se se tratasse de um adulto em miniatura, o franzino Edmund perambula pelas ruínas de Berlim deixando-nos em permanente estranheza diante de sua silhueta magérrima, suas roupas de homenzinho, suas feições duras e sua voz aguda e demasiado infantil para seus 12 anos. A expressão do rosto é sempre impenetrável.

Como escreve Bazin (2018, p. 409):

Rossellini não faz seus atores interpretar, não os faz expressar este ou aquele sentimento, mas os obriga apenas a ficar de uma determinada maneira diante da câmera. Nesse tipo de mise-en-scène, o lugar respectivo dos personagens, a maneira de andar, de se deslocar no cenário, seus gestos têm muito mais importância do que os sentimentos que se desenham sobre seus rostos, ou mesmo do que o que eles dizem.

Não obstante essa aparente impenetrabilidade, Edmund, o corpo-fiapo, o corposombra, carrega em si a eloquência, mais do que de um discurso, de um grito. Sua 
perambulação constante, sua busca incessante pela sobrevivência dele e dos seus fazem dele um autômato num corpo de criança. Edmund quase que se mistura à paisagem de concreto, pó e pedras.

Tanto quanto Edmund, o sargento interpretado por Lee Marvin em The Big Red One, carrega em si, na economia de gestos e expressões, a eloquência de um discurso. Como Fuller escreveu, ao falar da escolha de Marvin para o papel: "O rosto da guerra mais enrugado, fatigado, mais cadavérico possível, mas precisamente por causa disso a morte não pode atingi-lo" (2002, p. 320, apud 2018, p. 52).

Que exagero de interpretação poderá existir ou se justificar diante do horror puro e simples do real? Que eloquência maior que a da personagem do sargento, em The Big Red One, na recriação ficcional do horror real testemunhado por Fuller em Falkenau, ao carregar nos braços a criança resgatada do campo, até que ela dê seu último suspiro?

Haverá mundo possível após o ano zero?

Certamente, em nosso modesto exercício warburguiano, poderíamos experimentar muitas outras intersecções possíveis entre as obras de Fuller e de Rossellini. Julgamos, porém, ao longo deste breve artigo, haver distribuído alguns indícios, apostas e linhas já suficientes para estabelecer um princípio de aproximação entre eles: a busca por uma espécie de pedagogia, uma centralidade (ainda que nem sempre acompanhada de protagonismo) na infância, uma linha de interpretação que investe mais na intensidade do corpo que na expressividade do rosto. Acima de todos esses aspectos, e de outros que sem dúvida poderíamos ainda desenvolver, finalizamos com este diálogo ficcional, mas nem por isso impossível:

- Make it artistic. But show the truth. [Faça de modo artístico. Mas mostre a verdade.] - Samuel Fuller.

- Volevo riprodurre la verità, sotto l'impulso di una forte emozione artistica. [Eu queria reproduzir a verdade, sob o impulso de uma forte emoção artística.] - Roberto Rossellini. ${ }^{5}$ 


\section{REFERÊNCIAS}

BAZIN, André. O que é o cinema? Trad. Eloísa Araújo Ribeiro. São Paulo: Ubu Editora, 2018.

BRUNETTE, Peter. Roberto Rossellini. Berkeley: University of California Press, 1996.

DANEY, Serge. Le travelling de Kapo (1992), Persévérance, Paris: P.OL., 1994.

DIDI-HUBERMAN, Georges. Atlas ou O gaio saber inquieto: o olho da História III. Belo Horizonte: Editora UFMG, 2018.

DIDI-HUBERMAN, Georges. Remontagens do tempo sofrido: o olho da história. Belo Horizonte: Editora UFMG, 2018.

FALDINI, Franca; FOFI, Goffred. L'avventurosa storia del cinema italiano racontata dai i suoi protagonisti. Milão: Feltrinelli, 1976.

FULLER, Samuel. A Third Face. My Tale of Writing, Fighting, and Fimmaking, ed. C. Lang Fuller e J. H. Rudes, New York: Applause, 2002.

MARTIN, Adrian. Samuel Fuller. Great Directors Database: Senses of Cinema 21 (July-August 2002).

MORIN, Edgar. $O$ ano zero da Alemanha. Trad.: Edgard de A. Carvalho e Mariza P. Bosco. Porto Alegre: Sulina, 2009.

NARDONI, Jean; SIMSOLO Noël. II était une fois... Samuel Fuller. Histoires d'Amérique, transcription e trad. D. Vilain, Paris, Cahiers du cinema, 1986.

ROSSELLINI, Roberto. Dix ans de cinema, part 2. Paris, Cahiers du Cinéma, n. 52, nov. 1955. 
ROSSELLINI, Roberto. Fragmentos de uma autobiografia. Trad.: Léa Novaes. Rio de Janeiro: Nova Fronteira, 1992a.

ROSSELLINI, Roberto. My Method: Writings \& Interviews. Edit. Adriano Aprà. Trad. Annapaola Cancogni. New York: Marsilio Publishers, 1992b.

ROSSELLINI, Roberto; VERGARA, Alain. Le cinema révélé. Paris: Cahiers du Cinéma, 2006. (Col. Petite Bibliothèque)

SERVER, Lee. Sam Fuller: Film Is a battleground - A critical study, with interviews, a filmography and a bibliography. North Carolina: McFarland \& Company, 1994.

WARBURG, Aby.

\section{FILMOGRAFIA}

ALEMANHA ano zero (Germania anno zero). Direção: Roberto Rossellini. País de produção: Itália. Ano de produção: 1948. Duração: 71 min. Preto e branco.

BIG Red One, The (Agonia e Glória). Direção: Samuel Fuller. País de produção: Estados Unidos. Ano de produção: 1980. Duração: 162 min. Colorido.

FALKENAU, vision du l'impossible. Direção: Emil Weiss / Samuel Fuller. País de Produção: França. Ano de produção: 1988. Duração: 114 min. Colorido e preto e branco.

PAISÀ (Paisà). Direção: Roberto Rossellini. País de produção: Itália. Ano de produção: 1946. Duração: 125 min. Preto e branco.

ROMA cidade aberta (Roma città aperta). Direção: Roberto Rossellini. País de produção: Itália. Ano de produção: 1945. Duração: 97 min. Preto e branco. 


\section{APÊNDICE - REFERÊNCIAS DE NOTA DE RODAPÉ}

2. Informação disponível em: https://encyclopedia.ushmm.org/content/ptbr/article/holocaust-denial-key-dates. Acesso em: 15 dez. 2020.

3. Informação disponível em: https://g1.globo.com/mundo/noticia/le-pen-econdenado-a-pagar-r-120-mil-por-dizer-que-camaras-de-gas-sao-detalhes-dasegunda-guerra.ghtml. Acesso em: 15 dez. 2020.

4. ROSENBAUM, J. Germany year zero, the humanity of the defeated. Disponivel em: http://www.criterion.com/current/posts/1358-germany-year-zero-the-humanity-of-thedefeated. Acesso em: 15 dez. 2020. Tradução nossa.)

5. Frase de Fuller extraída de: DIDI-HUBERMAN, Georges, 2018, p. 51; frase de Rossellini extraída de: ROSSELLINI, Roberto. I/ mio metodo: scritti e interviste. Edit. Adriano Aprà. Marsilio Editori, 2006.

Enviado: Dezembro, 2020.

Aprovado: Dezembro, 2020. 